\title{
Role of endothelium, acetylocholine and calcium ions in Bay K8644- and KCl-induced contraction
}

\author{
KATARZYNA SZADUJKIS-SZADURSKA*, GRZEGORZ GRZESK*, LESZEK SZADUJKIS-SZADURSKI, \\ MARTA GAJDUS, BARTOSZ MALINOWSKI and MICHAL WICINSKI
}

Department of Pharmacology and Therapeutics, Collegium Medicum Nicolaus Copernicus University, Bydgoszcz 85-094, Poland

Received February 17, 2013; Accepted June 13, 2013

DOI: $10.3892 / \mathrm{mmr} .2013 .1574$

\begin{abstract}
The aim of this study was to establish the involvement of acetylcholine (Ach) and calcium ions in modulating contractions induced by Bay K8644 (an agonist of calcium channels located in the cell membrane) and $\mathrm{KCl}$ (at depolarizing concentrations), and also to examine the importance of the vascular endothelium in the activity of Bay K8644. The study was performed on perfused Wistar rat tail arteries. Contraction induced by Bay K8644 with the participation of intracellular (in calcium-free physiological salt solution, FPSS) and extracellular (in physiological salt solution, PSS, following the emptying of the cellular $\mathrm{Ca}^{2+}$ stores) pools of $\mathrm{Ca}^{2+}$ and the addition of nitro-L-arginine (L-NNA; nitric oxide synthase inhibitor) or $1 \mathrm{H}-(1,2,4)$ oxadiazolo(4,3-a)quinoxalin-1-one (ODQ; an inhibitor of soluble guanylyl cyclase) was studied. In addition, the effect of Ach on the contraction response was analyzed and the results were compared with the depolarizing action of $\mathrm{KCl}$. The effects of $8 \mathrm{Br}-\mathrm{cGMP}$ on the artery contraction induced by Bay K8644 prior to and following removal of the endothelium were compared. Bay $\mathrm{K} 8644$ and $\mathrm{KCl}$ in PSS induced vascular contraction, which was reduced with the addition of Ach. The spasmolytic Ach action did not occur in the presence of L-NNA and ODQ. 8Br-cGMP reduced the contraction of arterial walls (with and without endothelium) induced by Bay K8644. The increase in vascular tone induced by Bay $\mathrm{K} 8644$ and $\mathrm{KCl}$ was independent of the intracellular calcium ion pool. The relaxant effect of Ach on the responses stimulated by Bay $\mathrm{K} 8644$ and $\mathrm{KCl}$ indicated the participation of nitric oxide in modulating the reactivity of the arteries to
\end{abstract}

Correspondence to: Dr Katarzyna Szadujkis-Szadurska, Department of Pharmacology and Therapeutics, Collegium Medicum Nicolaus Copernicus University, 9 Sklodowskiej-Curie Street, Bydgoszcz 85-094, Poland

E-mail: kataszsz@gmail.com

*Contributed equally

Key words: contraction, bay $\mathrm{K} 8644, \mathrm{KCl}$, calcium ions, acetylocholine, endothelium the factors examined, resulting in an influx of $\mathrm{Ca}^{2+}$ into the cell.

\section{Introduction}

The structure of the arteries is important as serve as a target for a number of substances that regulate smooth muscle tension. The endothelium is a cell layer that lines the inside of blood vessels, and also produces and releases mediators that modulate the contraction of arteries $(1,2)$.

Endothelial damage occurs in the course of various pathological processes, particularly atherosclerosis, and leads to vascular disorders with regard to diameter regulation, which potentially result in occlusion of the vessels. Although platelet aggregation is a natural recovery process following the injury of blood vessel walls, activation of the coagulation system following plaque rupture may result in a reduction or complete elimination of blood flow. Nitric oxide (NO) is a vasodilator agent that is produced by the endothelial cells by constitutive NO synthase (3). In smooth muscle cells, NO activates soluble guanylyl cyclase (GC) and the resulting increase in cyclic guanosine monophosphate (cGMP) levels leads to blood vessel dilatation $(4,5)$. This effect may be as a result of the reduction in the concentration of $\mathrm{Ca}^{2+}$ in the cytoplasm (due to the influx of calcium into the cell or the inhibition of the release of calcium from intracellular stores), dephosphorylation of myosin light chains or interaction with the contractile system (6-10). The release of NO occurs under physiological conditions; however, it may be further stimulated by various factors, such as acetylcholine (Ach), bradykinin and histamine (11).

The aim of this study was to determine the significance of the signaling pathway associated with Ach in the contraction induced via the extracellular pool of $\mathrm{Ca}^{2+}$ by Bay $\mathrm{K} 8644$ (an agonist of calcium channels located in the cell membrane) and $\mathrm{KCl}$ (at depolarizing concentrations), and also to determine the importance of the vascular endothelium in the activity of Bay K8644.

\section{Materials and methods}

Reagents. The study was performed on perfused male Wistar rat tail arteries. Rats, weight 250-350 g, were narcotized by 
Table I. EC E0 values for Bay K8644 in the presence of 8Br-cGMP (experiments performed on arteries with/without endothelium).

\begin{tabular}{lcr} 
Group & $\mathrm{EC}_{50}$ arteries with endothelium & EC $_{50}$ arteries without endothe \\
\hline Bay K8644 (control) & $5.97( \pm 0.21) \times 10^{-8}$ & $1.37( \pm 0.24) \times 10^{-8}$ \\
$8 \mathrm{Br}-\mathrm{cGMP}(10 \mu \mathrm{M} / \mathrm{l})$ & $4.07( \pm 0.29) \times 10^{-7}$ & $3.47( \pm 0.21) \times 10^{-8}$ \\
$8 \mathrm{Br}-\mathrm{cGMP}(30 \mu \mathrm{M} / \mathrm{l})$ & $5.67( \pm 0.26) \times 10^{-7}$ & $2.17( \pm 0.26) \times 10^{-7}$ \\
$8 \mathrm{Br}-\mathrm{cGMP}(100 \mu \mathrm{M} / \mathrm{l})$ & $7.12( \pm 0.32) \times 10^{-7}$ & $6.12( \pm 0.22) \times 10^{-7}$ \\
\hline
\end{tabular}

Values are presented as the mean $\pm \mathrm{SD}$. $\mathrm{EC}_{50}$, half maximal effective concentration; cGMP, cyclic guanosine monophosphate.

intraperitoneal injection of $120 \mathrm{mg} / \mathrm{kg}$ of body mass. After being dissected and cleared from the surrounding tissue, $2.5-3-\mathrm{cm}$ long segments of rat tail arteries were cannulated and connected to perfusion apparatus. Perfusion pressure was measured continuously. The distal part was weighted with a $500 \mathrm{mg}$ weight and placed in a $20 \mathrm{ml}$ container filled with oxygenated Krebs solution at $37^{\circ} \mathrm{C}$. The perfusion solution flow was gradually increased using a peristaltic pump until $1 \mathrm{ml} / \mathrm{min}$ was reached.

Two types of Krebs fluid were used in this study to determine the importance of the intracellular and extracellular pools of $\mathrm{Ca}^{2+}$ in the reactions induced by Bay $\mathrm{K} 8644(30 \mu \mathrm{M} / \mathrm{l})$ and $\mathrm{KCl}(110 \mathrm{mM} / \mathrm{l})$ under control conditions, following the addition of nitro-L-arginine (L-NNA; nitric oxide synthase, $10 \mu \mathrm{M} / 1)$ or $1 \mathrm{H}-(1,2,4)$ oxadiazolo(4,3-a)quinoxalin-1-one (ODQ; an inhibitor of soluble guanylyl cyclase; $10 \mu \mathrm{M} / 1$ ), and in the presence of increasing Ach concentrations. The two Krebs solutions were as follows: i) fluid without $\mathrm{Ca}^{2+}$-EGTA [Krebs (no calcium); calcium-free physiological salt solution, FPSS]; and ii) fluid with $\mathrm{Ca}^{2+}$-EGTA [Krebs (normal); physiological salt solution, PSS]. The composition of the fluid without $\mathrm{Ca}^{2+}$-EGTA was as follows: $\mathrm{NaCl}(71.8 \mathrm{mM} / \mathrm{l}), \mathrm{KCl}(4.7 \mathrm{mM} / \mathrm{l})$, $\mathrm{NaHCO}_{3}(28.4 \mathrm{mM} / \mathrm{l}), \mathrm{MgSO}_{4}(2.4 \mathrm{mM} / \mathrm{l}), \mathrm{KH}_{2} \mathrm{PO}_{4}(1.2 \mathrm{mM} / \mathrm{l})$, glucose $(11.1 \mathrm{mM} / \mathrm{l})$ with the addition of EGTA $(30 \mu \mathrm{M} / \mathrm{l})$. The composition of the fluid with $\mathrm{Ca}^{2+}$-EGTA was as follows: $\mathrm{NaCl}(71.8 \mathrm{mM} / \mathrm{l}), \mathrm{KCl}(4.7 \mathrm{mM} / \mathrm{l}), \mathrm{CaCl}_{2}(1.7 \mathrm{mM} / \mathrm{l}), \mathrm{NaHCO}_{3}$ (28.4 mM/l), $\mathrm{MgSO}_{4}(2.4 \mathrm{mM} / \mathrm{l}), \mathrm{KH}_{2} \mathrm{PO}_{4}(1.2 \mathrm{mM} / \mathrm{l})$, glucose $(11.1 \mathrm{mM} / \mathrm{l})$ with addition of EGTA $(30 \mu \mathrm{M} / \mathrm{l})$, following the emptying of the intracellular pool of $\mathrm{Ca}^{2+}$. All reagents were purchased from Sigma-Aldrich (Poznań, Poland).

Removal of the endothelium. In a number of cases, the endothelium of the arteries was removed using compressed air to determine the importance of the endothelium in the responses induced by Bay K8644 and following the addition of increasing concentrations of 8Br-cGMP (12).

Concentration-response curves (CRCs). CRCs were determined using the van Rossum method of increasing concentrations (12). Dose-dependency was determined for arteries with and without endothelium under control conditions and in the presence of 8Br-cGMP (10, 30 and $100 \mu \mathrm{M} / \mathrm{l})$. The concentration of $8 \mathrm{Br}-\mathrm{cGMP}$ that resulted in the half maximal effective concentration $\left(\mathrm{EC}_{50}\right)$ was determined using the method of linear regression for $20-80 \%$ maximal effect. Vessel contraction was measured as increase in perfusion pressure.

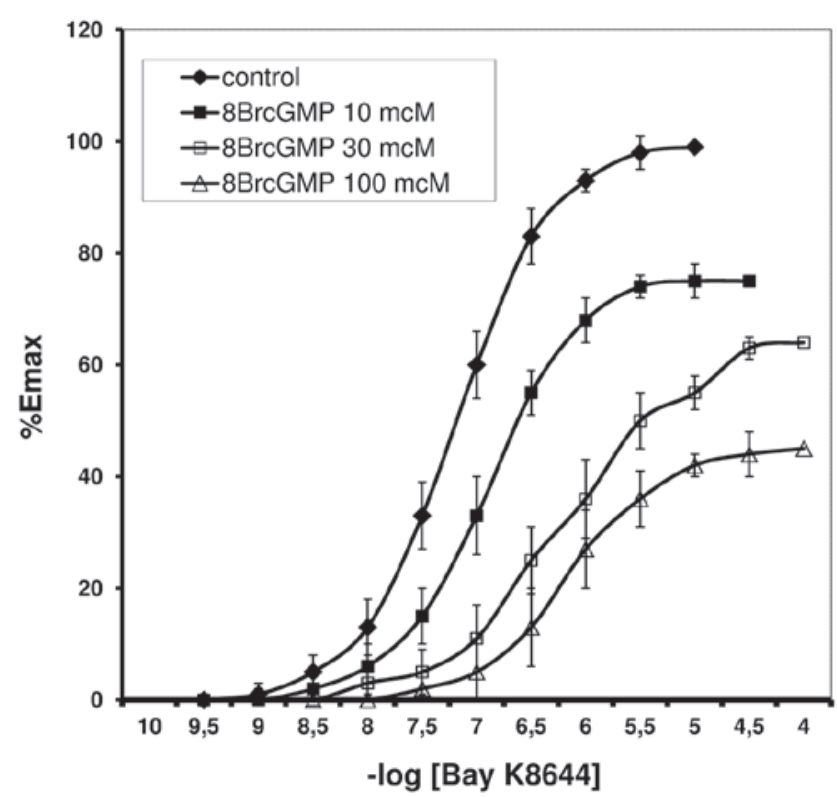

Figure 1. Concentration-response curves for Bay K8644 demonstrating the effect of 8Br-cyclic guanosine monophosphate (cGMP) on contraction of arteries with endothelium. Mean $\pm \mathrm{SD}, \mathrm{n}=8$.

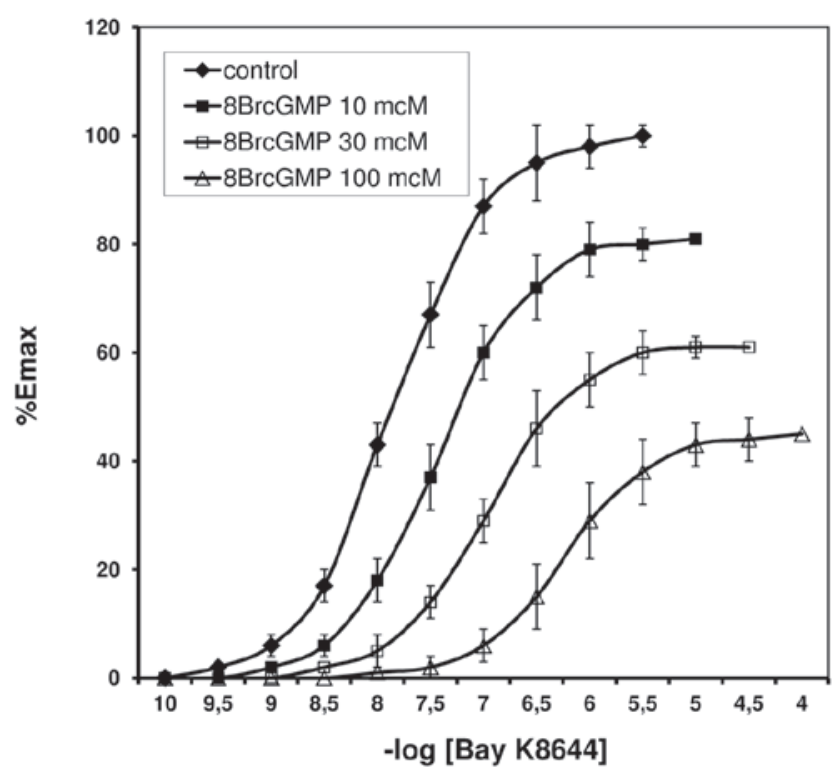

Figure 2. Concentration-response curves for Bay K8644 demonstrating the effect of 8Br-cyclic guanosine monophosphate (cGMP) on contraction of arteries without endothelium. Mean $\pm \mathrm{SD}, \mathrm{n}=8$. 


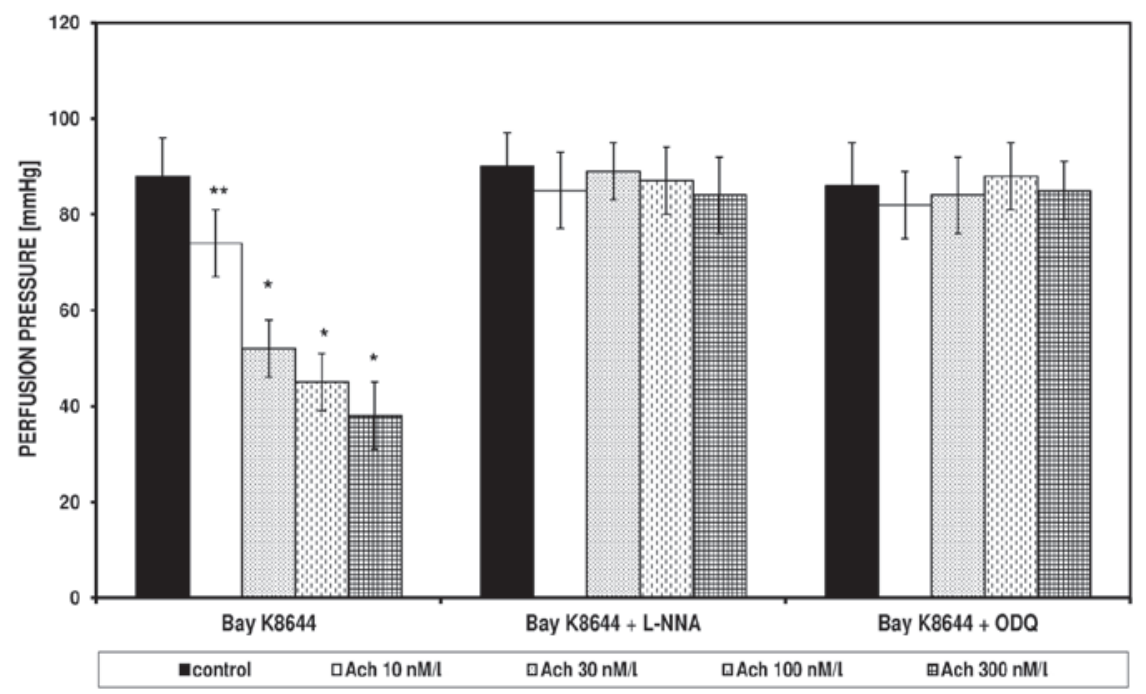

Figure 3. The influence of acetylocholine on the contraction induced by Bay $\mathrm{K} 8644$ (30 mM/l) in physiological salt solution (PSS), in the presence of nitro-L-arginine (L-NNA) $(10 \mu \mathrm{M} / 1)$ and $1 \mathrm{H}-(1,2,4)$ oxadiazolo(4,3-a)quinoxalin-1-one (ODQ) $(10 \mu \mathrm{M} / 1)$; (mean $\pm \mathrm{SD}, \mathrm{n}=12)$; ${ }^{*} \mathrm{P}<0.0001$ vs. control and ${ }^{* * *} 0.0001<\mathrm{P}<0.05$ vs. control.

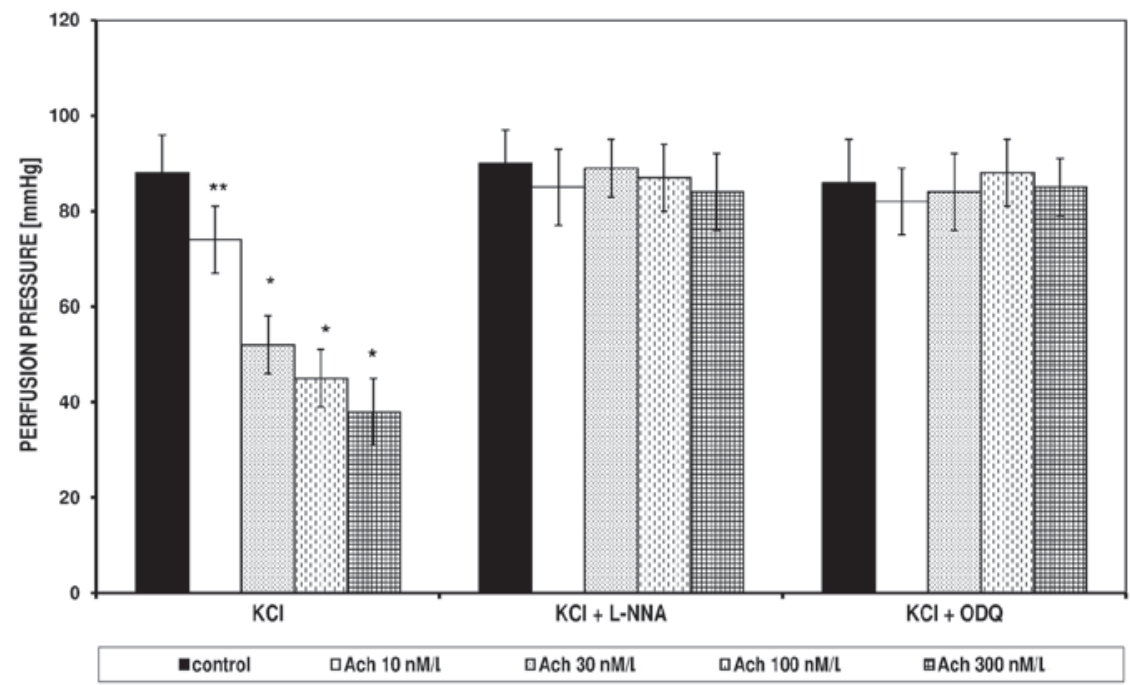

Figure 4. The effect of acetylocholine on the contraction induced by $\mathrm{KCl}(110 \mathrm{mM} / \mathrm{l})$ in physiological salt solution (PSS), in the presence of nitro-L-arginine (L-NNA) $(10 \mu \mathrm{M} / \mathrm{l})$ and 1H-(1,2,4)oxadiazolo(4,3-a)quinoxalin-1-one (ODQ) $(10 \mu \mathrm{M} / 1)$; (mean $\pm \mathrm{SD}, \mathrm{n}=12)$; ${ }^{*} \mathrm{P}<0.0001$ vs. control and ${ }^{* *} 0.0001<\mathrm{P}<0.05 \mathrm{vs}$. control.

Ethical compliance. The Guiding Principles for the Care and Use of Animals in the Field of Physiological Sciences as well as specific national law were followed. The study was approved by the Ethics Committee for the Affairs of Experiments on Animals in Bydgoszcz (no. 1/2008-4).

Statistical analysis. Results are presented as the mean \pm standard deviation. Statistical differences were analyzed using the Student's t-test. $\mathrm{P}<0.05$ was considered to indicate a statistically significant difference.

\section{Results}

Bay K8644 induced contraction of the rat tail arteries with and without endothelium. CRCs for Bay K8644, in the presence of $8 \mathrm{Br}-\mathrm{cGMP}$ are shown in Figs. 1 and 2. The resulting $\mathrm{EC}_{50}$ values are listed in Table I.

In the FPSS group, perfusion pressure under the influence of Bay K8644 and $\mathrm{KCl}$ did not change; the pressures were $14 \pm 6$ and $15 \pm 5 \mathrm{mmHg}$, respectively (data not shown). Bay K8644 and $\mathrm{KCl}$ in the PSS induced an increase of perfusion pressure, which was significantly reduced in the presence of Ach (Figs. 3 and 4). The spasmolytic Ach action did not occur in the presence of L-NNA and ODQ. Figs. 3 and 4 present the effect of increasing concentrations of Ach on the perfusion pressure induced in the PSS by Bay $\mathrm{K} 8644$ and $\mathrm{KCl}$, respectively, in the presence of L-NNA and ODQ.

\section{Discussion}

Arterial tension is dependent upon the structure and function of each layer of the arterial wall, the availability of $\mathrm{Ca}^{2+}$ 
and the presence of certain vasodilator and vasoconstrictor factors. Endothelial NO is important in the induction of vasodilation (1), and acts through a signaling system involving cGMP (4,5). Bay $\mathrm{K} 8644$ and $\mathrm{KCl}$ are agents that stimulate blood vessel contraction by inducing an influx of $\mathrm{Ca}^{2+}$ into the cells through channels in the cell membrane. In the present study, the role of the endothelium in vascular contraction induced by Bay K8644 and the involvement of the Ach/NO/cGMP cascade in Bay K8644 and $\mathrm{KCl}$ activity were investigated.

Arterial spasm induced by Bay K8644 was demonstrated to be reduced by $8 \mathrm{Br}-\mathrm{cGMP}$, in a dose-dependent manner. The CRCs were shifted to the right with increasing 8Br-cGMP concentrations. Similar changes in the shape and position of the CRCs were demonstrated in the experiments performed in arteries without endothelium, thus the reaction was determined to be independent of this layer of the vessel wall. Similar findings were observed in previous studies, which utilized angiotensin II (ANG II) as a substance that stimulated vessel contraction $(13,14)$. These studies also demonstrated that in arteries without endothelium, in contrast to vessels with an intact inner layer, no inhibition of ANG II-stimulated contraction following ischemia was observed. Numerous studies have confirmed that ischemia/reperfusion results in an impaired endothelial function, which reduces the synthesis of endothelial vasodilatators, such as prostaglandins and NO (15-18).

Under these conditions, vasodilatation stimulated by Ach, bradykinin, adenosine-5'-diphosphate (ADP), serotonin and thrombin, among others, is disturbed; however, the effect of NO donors remains to be observed $(17,19)$. In the present study, experiments in FPSS and PSS demonstrated that Bay $\mathrm{K} 8644$ and $\mathrm{KCl}$ induce an increase in the perfusion pressure, due to an influx of $\mathrm{Ca}^{2+}$ from outside of the cell, as observed in previous studies (20-23). Other studies have indicated that $\mathrm{KCl}$ (at depolarizing concentrations) and Bay K8644 contract smooth muscle by opening the $\mathrm{Ca}^{2+}$ L-type channels located in the cell membrane, and by increasing concentrations of free $\mathrm{Ca}^{2+}$ in the cytoplasm. This effect may be eliminated in the presence of calcium channel $\mathrm{Ca}^{2+}$ antagonists, nifedipine and diltiazem (24-27). Subsequent experiments demonstrated that the contraction induced by Bay $\mathrm{K} 8644$ and $\mathrm{KCl}$ in the PSS was reduced at increasing Ach concentrations, and this effect was eliminated in the presence of L-NNA (nitric oxide synthase inhibitor) or ODQ (an inhibitor of soluble GC). In addition, similar observations have been demonstrated in studies of human mesenteric arteries (22). Ji et al demonstrated that Ach blocked phenylephrine-triggered contraction of endothelium-intact rat aorta, but did not affect the responses of arteries without endothelium (28).

The studies have also indicated that L-NNA and methylene blue (an inhibitor of soluble GC) may abolish the spasmolytic action of Ach. It was demonstrated that $\mathrm{KCl}$ stimulates the influx and increase of the calcium ion concentration in the cytoplasm, and also increases the myosin light chain kinase activity (29-31). However, the cellular mechanism of contraction induced by $\mathrm{KCl}$ remains to be elucidated.

This mechanism of action was the basis for the use of $\mathrm{KCl}$ in the present study investigating cell signaling as a factor in cell membrane depolarizing (electromechanical coupling), compared with agents that stimulate muscle contraction when combined with the corresponding receptors (pharmacomechanical coupling) $(31,32)$. Other studies have demonstrated that $\mathrm{KCl}$ may lead to the release of $\mathrm{Ca}^{2+}$ from intracellular stores $(33,34)$. It was also shown that membrane depolarization alone led to the sensitivity to $\mathrm{Ca}^{2+}(35)$. Studies have indicated that $\mathrm{KCl}$ also blocked the myosin light chain phosphatase through RhoA kinase activation, which led to the sensitivity of $\mathrm{Ca}^{2+}(36-38)$.

Signal pathways that control smooth muscle tension remain an important focus of research, as the mechanisms regulating vascular contraction may contribute to the understanding of physiological and pathological processes in the circulatory system, and may also be beneficial in determining novel treatment methods for cardiovascular diseases.

In conclusion, it was demonstrated that the increase in vascular tone induced by Bay $\mathrm{K} 8644$ and $\mathrm{KCl}$ was independent of the intracellular pool of $\mathrm{Ca}^{2+}$. The relaxant effect of Ach on the responses stimulated by Bay $\mathrm{K} 8644$ and $\mathrm{KCl}$ indicated that $\mathrm{NO}$ was involved in modulating the reactivity of the arteries to the examined factors, which contributes to the influx of $\mathrm{Ca}^{2+}$ into the cell.

\section{References}

1. Furchgott RF and Zawadzki JW: The obligatory role of endothelial cells in the relaxation of arterial smooth muscle by acetylcholine. Nature 288: 373-376, 1980.

2. Lüscher TF and Barton M: Biology of the endothelium. Clin Cardiol 20 (Suppl 2): II-3-II-10, 1997.

3. Palmer RM, Ashton DS and Moncada S: Vascular endothelial cells synthesize nitric oxide from L-arginine. Nature 333: 664-666, 1988.

4. Furchgott RF and Vanhoutte PM: Endothelium-derived relaxing and contracting factors. FASEB J 3: 2007-2018, 1989.

5. Murad F: The nitric oxide-cyclic GMP signal transduction system for intracellular and intercellular communication. Recent Prog Horm Res 49: 239-248, 1994.

6. Blatter LA and Wier WG: Nitric oxide decreases $\left[\mathrm{Ca}^{2+}\right] \mathrm{i}$ in vascular smooth muscle by inhibition of the calcium current. Cell Calcium 15: 122-131, 1994.

7. Collins P, Griffith TM, Henderson AH and Lewis MJ: Endothelium-derived relaxing factor alters calcium fluxes in rabbit aorta: a cyclic guanosine monophosphate-mediated effect. J Physiol 381: 427-437, 1986.

8. Karaki H, Sato K, Ozaki H and Murakami K: Effects of sodium nitroprusside on cytosolic calcium level in vascular smooth muscle. Eur J Pharmacol 156: 259-266, 1988.

9. McDaniel NL, Chen XL, Singer HA, Murphy RA and Rembold CM: Nitrovasodilators relax arterial smooth muscle by decreasing $\left[\mathrm{Ca}^{2+}\right] \mathrm{i}$ and uncoupling stress from myosin phosphorylation. Am J Physiol 263: C461-C467, 1992.

10. Murad F: Cyclic guanosine monophosphate as a mediator of vasodilation. J Clin Invest 78: 1-5, 1986.

11. Moncada S, Palmer RM and Higgs EA: Nitric oxide: physiology, pathophysiology, and pharmacology. Pharmacol Rev 43: 109-142, 1991.

12. Van Rossum JM: Cumulative dose-response curves. II. Technique for the making of dose-response curves in isolated organs and the evaluation of drug parameters. Arch Int Pharmacodyn Ther 143: 299-330, 1963

13. Koller A, Sun D, Huang A and Kaley G: Corelease of nitric oxide and prostaglandins mediates flow-dependent dilation of rat gracilis muscle arterioles. Am J Physiol 267: H326-H332, 1994.

14. Szadujkis-Szadurska K, Slupski M, Szadujkis-Szadurski R, Szadujkis-Szadurski L, Jasiñski M and Kolodziejska R: The role of the endothelium in the regulation of vascular smooth muscle cell contractions induced by angiotensin II after ischemia and reperfusion. Arch Pharm Res 33: 1019-1024, 2010.

15. Dignan RJ, Dyke CM, Abd-Elfattah AS, Lutz HA, Yeh T Jr, Lee KF, Parmar J and Wechsler AS: Coronary artery endothelial cell and smooth muscle dysfunction after global myocardial ischemia. Ann Thorac Surg 53: 311-317, 1992. 
16. Fullerton DA, Hahn AR, Koike K, Banerjee A and Harken AH: Intracellular mechanisms of pulmonary vasomotor dysfunction in acute lung injury caused by mesenteric ischemia-reperfusion. Surgery 114: 360-367, 1993.

17. Fullerton DA, Mitchell MB, McIntyre RC Jr, Banerjee A, Campbell DN, Harken AH and Grover FL: Cold ischemia and reperfusion each produce pulmonary vasomotor dysfunction in the transplanted lung. J Thorac Cardiovasc Surg 106: 1213-1217, 1993.

18. Hashimoto K, Pearson PJ, Schaff HV and Cartier R: Endothelial cell dysfunction after ischemic arrest and reperfusion: a possible mechanism of myocardial injury during reflow. J Thorac Cardiovasc Surg 102: 688-694, 1991.

19. Dauber IM, VanBenthuysen KM, McMurtry IF, Wheeler GS, Lesnefsky EJ, Horwitz LD and Weil JV: Functional coronary microvascular injury evident as increased permeability due to brief ischemia and reperfusion. Circ Res 66: 986-998, 1990.

20. Pesic A, Madden JA, Pesic M and Rusch NJ: High blood pressure upregulates arterial L-type $\mathrm{Ca}^{2+}$ channels: is membrane depolarization the signal? Circ Res 94: e97-e104, 2004.

21. Pratt PF, Bonnet S, Ludwig LM, Bonnet $\mathrm{P}$ and Rusch NJ: Upregulation of L-type $\mathrm{Ca}^{2+}$ channels in mesenteric and skeletal arteries of SHR. Hypertension 40: 214-219, 2002.

22. Szadujkis-Szadurski R, Tafil-Klawe M, Szadujkis-Szadurska K, Szadujkis-Szadurski L, Slupski M, Grzesk G, Matusiak G, Gajdus M and Glaza I: Modulation of the contractile effect of Bay K8644 on human vascular smooth muscle cells by acetylocholine and calcium ions. Med Biol Sci 24: 59-64, 2010.

23. Szadujkis-Szadurska K, Grzesk G, Szadujkis-Szadurski L, Gajdus M and Matusiak G: Role of nitric oxide and cGMP in modulation of vascular contraction induced by angiotensin II and Bay K8644 during ischemia/reperfusion. Exp Ther Med 5: 616-620, 2013

24. Iesaki T and Wolin MS: Thiol oxidation activates a novel redox-regulated coronary vasodilator mechanism involving inhibition of $\mathrm{Ca}^{2+}$ influx. Arterioscler Thromb Vasc Biol 20 2359-2365, 2000.

25. Matchkov VV, Aalkjaer C and Nilsson H: A cyclic GMPdependent calcium-activated chloride current in smooth-muscle cells from rat mesenteric resistance arteries. J Gen Physiol 123: 121-134, 2004

26. Piper AS and Large WA: Direct effect of $\mathrm{Ca}^{2+}$-calmodulin on cGMP-activated $\mathrm{Ca}^{2+}$-dependent $\mathrm{Cl}$-channels in rat mesenteric artery myocytes. J Physiol 559: 449-457, 2004.
27. Szadujkis-Szadurski L, Talar J, Wisniewski K, Tomaszewski W, Lukowicz M and Szadujkis-Szadurski R: Modulatory effects of laser radiation on extracellular and intracellular calcium pool and vascular resistance of rat's tail artery. Physiother Pol 2: 11-20, 2002.

28. Ji J, Benishin CG and Pang PK: Nitric oxide selectively inhibits intracellular $\mathrm{Ca}^{2+}$ release elicited by inositol trisphosphate but not caffeine in rat vascular smooth muscle. J Pharmacol Exp Ther 285: 16-21, 1998.

29. Brozovich FV: Rho signaling: agonist stimulation and depolarization come together. Circ Res 93: 481-483, 2003

30. Liu C, Zuo J, Pertens E, Helli PB and Janssen LJ: Regulation of Rho/ROCK signaling in airway smooth muscle by membrane potential and $\left[\mathrm{Ca}^{2+}\right]$ i. Am J Physiol Lung Cell Mol Physiol 289: L574-L582, 2005.

31. Somlyo AV and Somlyo AP: Electromechanical and pharmacomechanical coupling in vascular smooth muscle. J Pharmacol Exp Ther 159: 129-145, 1968

32. Karaki H, Ozaki H, Hori M, Mitsui-Saito M, Amano K, Harada K, Miyamoto S, Nakazawa H, Won KJ and Sato K: Calcium movements, distribution, and functions in smooth muscle. Pharmacol Rev 49: 157-230, 1997.

33. Kobayashi S, Kanaide $\mathrm{H}$ and Nakamura M: Complete overlap of caffeine- and $\mathrm{K}^{+}$depolarization-sensitive intracellular calcium storage site in cultured rat arterial smooth muscle cells. J Biol Chem 261: 15709-15713, 1986.

34. Ureña J, del Valle-Rodríguez A and López-Barneo J: Metabotropic $\mathrm{Ca}^{2+}$ channel-induced calcium release in vascular smooth muscle. Cell Calcium 42: 513-520, 2007.

35. Yanagisawa T and Okada Y: $\mathrm{KCl}$ depolarization increases $\mathrm{Ca}^{2+}$ sensitivity of contractile elements in coronary arterial smooth muscle. Am J Physiol 267: H614-H621, 1994.

36. Ratz PH, Berg KM, Urban NH and Miner AS: Regulation of smooth muscle calcium sensitivity: $\mathrm{KCl}$ as a calcium-sensitizing stimulus. Am J Physiol Cell Physiol 288: C769-C783, 2005.

37. Ratz PH and Miner AS: Role of protein kinase Czeta and calcium entry in $\mathrm{KCl}$-induced vascular smooth muscle calcium sensitization and feedback control of cellular calcium levels. J Pharmacol Exp Ther 328: 399-408, 2009.

38. Sakurada S, Takuwa N, Sugimoto N, Wang Y, Seto M, Sasaki Y and Takuwa Y: $\mathrm{Ca}^{2+}$-dependent activation of Rho and Rho kinase in membrane depolarization-induced and receptor stimulation-induced vascular smooth muscle contraction. Circ Res 93: 548-556, 2003. 